266

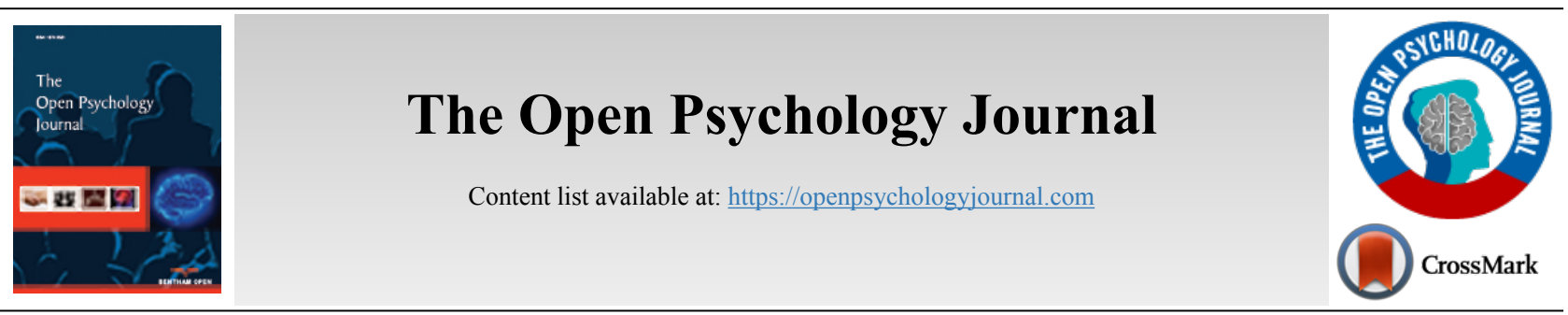

RESEARCH ARTICLE

\title{
Strategies of Prosocial Behavior During the COVID-19 Pandemic
}

\author{
Pavel A. Kislyakov ${ }^{1, *}$ and Elena A. Shmeleva ${ }^{1}$ \\ ${ }^{l}$ Russian State Social University, 4 Wilhelm Pieck Street, Moscow, Russia
}

\begin{abstract}
:
Background:

To mitigate the potentially devastating effects of the COVID-19 pandemic, it is vital to identify psychosocial and moral resources. The care, preservation, protection, and well-being of social communities are attributes of prosocial behavior that can be such a resource.

Aim:

The purpose of the study is to identify the features of prosocial orientation during the COVID-19 pandemic.

\section{Methods:}

The sample consisted of 447 people. The study was conducted in May 2020 in the form of an online survey of subjects using Google Forms ("Portrait Values Questionnaire").

Results:

The research made it possible to establish that participants were dominated by values of benevolence-universalism. During the COVID-19 pandemic, the prosocial orientation may manifest itself in the following behavioral strategies: proactive prosocial strategy of "caring for others" (true altruism, expressed in forms of volunteering, helping a stranger, and charity despite the risk of contracting a coronavirus infection); egoistic strategy of prosocial behavior "self-care through caring for others" (volunteering based on self-development; helping a stranger to improve your own psychological well-being); conventional prosocial strategy "self-care" (self-isolation and preventive behavior).

Conclusion:

In the long run, it is necessary to identify personal and environmental resources that can allow people to effectively implement a prosocial selfisolation strategy during the COVID-19 pandemic, as well as various forms of volunteerism.
\end{abstract}

Keywords: Prosocial orientation, Prosocial behavior, Strategy, Self-care, Care for others, COVID-19 pandemic, Psychological safety.

\section{Article History} Received: February 03, 2021 Revised: July 05, 2021 Accepted: July 30, 2021

\section{INTRODUCTION}

Changing our collective behavior is crucial to saving lives in the face of a new infectious disease. To mitigate the potentially devastating effects of the COVID-19 pandemic, it is vital to identify psychosocial and moral resources [1]. The care, preservation, protection, and well-being of social communities (another person, team, social organization, etc.) are attributes of prosocial behavior that can be such a resource. Addressing the prosocial orientation of an individual can be an important aspect of the response to social dilemmas during the pandemic [2].

\footnotetext{
* Address correspondence to this author at the Russian State Social University, 4 Wilhelm Pieck str., Moscow, Russia; Tel: +7-915-848-4010;
}

E-mail: pack.81@mail.ru
Psychologists, sociologists, anthropologists, biologists have noted that prosocial behavior is a central aspect of human life and the focus of research in the natural and social sciences [3]. Prosocial behavior refers to a broad category of acts that are generally beneficial to other people or society and includes behaviors such as cooperating, resource sharing, and helping $[4,5]$. The prosocial orientation of an individual is characterized by a system of motivations associated with activities for the benefit of others and society as a whole, with a sense of duty, responsibility to the group or society. In the case of prosocial orientation, the individual is identified with the group.

Prosocial orientation and behavior can be based on both moral norms based on the principles of justice and care, and 
selfish motives based on the satisfaction of one's own needs. Based on an interdisciplinary approach and anthropological research results, the intentionality of morality in the relationship between self-caring and caring for others has been established, revealing the paradox of self-caring: "the self-care ability develops when we care for others" [6 - 9].

Human values and social norms are essential in creating the possibility that people obey behavioral demands and display prosocial behavior. There is evidence that values of self-transcendence and security [1, 10 - 13] predict prosocial behaviors (charity, voluntary assistance, cooperation, empathy).

Thus, the values shared by society may be a key binding factor in promoting the collective prosocial orientation necessary during the COVID-19 pandemic. It is the valuesemantic component of the prosocial orientation that determines the main relations of a person to the world and to himself. In this intention, the conditionality of prosocial behavior manifests itself. This relationship is the basis for the study of value orientations, as well as preferred strategies of prosocial behavior during the transformation of social interactions caused by COVID-19 [14].

\subsection{Literature Review}

In response to COVID-19, self-help groups and medical volunteers have become widespread in many countries [15 18]. In order to support people in terms of the pandemic, Russia has launched the "We Are Together" mutual assistance campaign, which includes medical, psychological, legal assistance, collection of donations to support the elderly, provision of healthcare facilities, and volunteer headquarters.

The online magazine "BRICS Business Magazine" in April 2020 launched a media project "COVID-19-the Correct Answer" (https://covid.bricsmagazine.com/). The goal of the media project is to draw attention to professionalism, altruism, caring, and empathy, which in all its forms helped individuals, cities, countries, and the whole of humanity to win the fight against the pandemic. The site contains stories about the helping behavior, heroism, and self-sacrifice of doctors, patients, scientists, teachers, politicians, civil servants, businessmen, law enforcement, military, civil activists, volunteers, journalists, and ordinary people [19].

Sociological studies conducted in Russia reveal some contradictory data. On the one hand, Russians demonstrate their attraction to prosocial orientation and to a selfish one, on the other hand. Thus, according to the results of the Levada Center sociological survey, half of those polled, replying to the question "What will happen to relationships between people in our country in the epidemic situation?", chose the following answer: "People will take more care only about themselves and 'their own"'; one third replied, "Nothing will change between people"; and only $17 \%$ supported the version "People will become more supportive of each other" [20].

In March-April 2020, the Institute of Psychology of the Russian Academy of Sciences conducted research on the attitude of Russians to the COVID-19 pandemic. The results of the research showed that one-third to half of the respondents demonstrated a prosocial orientation («I forward information to my friends and acquaintance that can help them during the epidemic» $-50 \%$; «I'm willing to donate money to help the elderly who fell ill during the epidemic» $-31 \%$, etc.) or prosocial perception («If my family gets sick, I am sure they will get the required help from other people» $-30 \%$, etc.) of others for a number of indicators [21].

In March-April 2020, The Russian Center for Public Opinion Research conducted a study on Russians' awareness of volunteer activities during the spread of coronavirus infection and their readiness to provide volunteer assistance themselves. More than half of the Russians (61\%) declared their readiness to provide volunteer assistance to people under quarantine, including single people. Every sixth Russian $(15 \%)$ has already had to provide gratuitous help to elderly people or those who were under home quarantine due to the coronavirus («Inform surrounding people about the ways of coronavirus transmission and methods of its prevention» - 19\%; («Clean entrances, common living areas» $-13 \%$; «Buy or produce your own protection and hygiene products» $-11 \%$; «Provide assistance in solving everyday problems» $-8 \%$; «Provide psychological help, support, psychological counseling»-7\%, etc.) [22].

In the face of a pandemic, a proactive strategy of prosocial behavior shall be a strategy of "caring for another person", which can exist in the form of volunteering, charity, and situational help to a stranger. The proactive strategy is based on the ethics of "love for a distant" and "duty motives", and is related to the ability to accumulate and use economically any kind of resources necessary to achieve time-distant life goals [23].

Sociological research data has generally reflected a tendency for volunteerism and charity in Russia in recent years. Thus, according to WCIOM sociological survey conducted in September 2019, 19\% of Russians are regularly engaged in charity or volunteering, and $68 \%$ are ready to engage in charity or volunteering in the future [24]. We may assume in this regard that the motives for providing assistance during the COVID-19 pandemic are also primarily selfish and related to self-actualization, social skills development, and increase of social contacts, etc., despite the risk of contracting coronavirus infection [25]. Thus, the second strategy of prosocial behavior during the COVID-19 pandemic is the selfish strategy of "selfcare through caring for others". At the same time, the mechanism of prosocial behavior realization can be the mechanism of psychological protection (coping) and development.

Raposa et al. showed that participation in prosocial behavior could be an effective strategy for reducing the impact of stress on psycho-emotional status [26]. Dawans et al. proved in laboratory conditions that people who experienced acute social stress showed more prosocial behavior (trust, reliability, and sharing) [27]. Thus, the authors arrived at the conclusion that participation in prosocial behavior in response to stress can be a protective pattern. V.G. Krysko notes that prosocial behavior leads to good social well-being of a human through reflexing [28]. G. Luria et al. showed that the avoidance of uncertainty was a predictor of volunteering and donations at the individual level [29]. 
Finally, the third strategy for prosocial behavior in a pandemic is the "self-care strategy", which manifests itself in the form of preventive or health-saving behavior [30]. The inextricable link between caring for others and self-care is evidenced by research on health-saving behaviors that consider self-care as an activity of individuals, families, and communities undertaken to promote health, prevent disease, and restore health. Research of processes in which self-care acts as a strategy for preserving an individual's identity indicates a deep, valuable, and moral motivation for healthsaving behavior [7]. For example, a study of the health-saving behavior of older people shows that individuals interpret selfcare practices as a moral obligation to society [31]. Caring for one's own health, a person retains his independence as well as the ability to take care of others [32].

A. Kappes et al. found that in hypothetical scenarios for deciding whether to go to work when sick, the American and British participants in the experiment reported that they would be less willing to stay home when it was doubtful that they would infect a colleague. However, when going to work, at the risk of infecting an older colleague who has a serious illness, the participants reported that they would be more willing to stay home. Thus, focusing on the worst-case scenarios, even if they are unsure, may encourage people to make sacrifices for others [33].

Preventive behavior during the COVID-19 pandemic should be linked to self-isolation and should aim to exclude or reduce their contact with others who may pose a threat to themselves or, conversely, to others, "to practice caring for their own being and that of others, to perform the work of the individual for their well-being - physical, mental, and spiritual - and to eliminate their own and others' disadvantage" [1,34]. Pfattheicher et al., conducting research in the UK, USA, and Germany, found that empathy (as the emotional basis for prosocial behavior) predicted and even increased motivation to observe the rules of physical distancing and wearing medical masks [35].

Most of the negative effects on the human psyche relate to the forced restriction of liberty. The "self-care strategy" adoption through voluntary self-isolation helps to reduce stress. Therefore, authorities and social institutions should emphasize altruism in their choice of self-isolation [36]. Awareness of prosocial behavior associated with observing the rules of social distance and hygiene forms a sense of collectivity and helps to prevent mental disorders caused by self-isolation [37].

Research by psychologists at the Institute of Psychology of the Russian Academy of Sciences showed that $70 \%$ of respondents believed that salvation from the COVID-19 pandemic was the moral consciousness and responsibility of each person. About $70 \%$ of respondents are also aware of the importance of preventive behavior during the COVID-19 pandemic (self-isolation and wearing masks) [21]. At the same time, as noted by T.A. Nestik, one of the reasons for observing the precautionary rules during the COVID-19 pandemic, along with fear of infection, is compassion for others (empathy) and solidarity with others [38].

Dryhurst and colleagues completed a study aimed at measuring the COVID-19 risk perception index in ten countries in Europe, America, and Asia. The index reflected people's perceptions of the danger of the COVID-19 pandemic, the perceived likelihood that they themselves, their family members, and friends would become infected with the virus, and the level of concern about the virus. The study found that prosocialism, expressed in recognition of the importance of doing something for the benefit of others and society, even to the detriment of personal interests, was more or less a predictor of awareness of the COVID-19 pandemic risks for people in all countries (from different cultures) [39].

According to the Russian Public Opinion Research Center, four out of five Russians (81\%) who participated in a sociological poll are self-isolating. Moreover, $76 \%$ have limited their contacts, stay at home, or have gone to a faraway location [40].

As D.A. Leontyev notes, sociological researches allow fixing the change of attitude to many realities being on the surface of consciousness [41]. Psychological research, on the other hand, deals with more stable mechanisms. In this regard, psychological research is required to study changes in prosocial orientation and to implement behavioral strategies based thereon during the COVID-19 pandemic. Our research is devoted to this problem solution.

Existing theoretical and empirical studies show, albeit indirectly, that firstly people are shifting towards prosocialism during the COVID-19 pandemic, and secondly, different strategies of prosocial behavior based on caring for others and/or self-concern are possible $[1,10]$. In addition, we have formulated the following hypotheses based on the evidence that values define forms of prosocial behavior [1, 13, 42]: 1) during the COVID-19 pandemic, the youth values are dominated by the prosocial orientation; 2) values can define three prosocial orientation strategies during the COVID-19 pandemic: proactive "caring for others" strategy, selfish "self-care through caring for others" strategy, and conventional preventive "selfcare" strategy.

\section{MATERIALS AND METHODS}

The sample consisted of 447 people ( $41 \%$ men, 59\% women) aged between 17 to 25 years $(M=20)$, university students in Moscow, Ivanovo, Kostroma, Yaroslavl; $57.7 \%$ had experience in volunteer activities. A sampling is formed from young persons because they are the most active and mobile part of society, involved in various social processes (including volunteering - as a form of prosocial behavior), and are faster to respond to the changes and adapt to them, including those related to the moral and value orientations. The procedure of "convenience" sampling was used; the students voluntarily took part in the research for additional points in the academic ranking.

The study was conducted in May 2020 in the form of an online survey of subjects using Google Forms. The prosocial orientation was assessed based on indicators of the value orientations.

The initial stimulus used for the survey was, "During the COVID-19 pandemic, it is important that people take care of 
the health and well-being of others. Care can be expressed in donations, participation in volunteer actions, psychological support, observance of social distance and rules of behavior, etc. Answer the questions given the COVID-19 pandemic situation".

Value orientations were investigated using a shortened version of the "Portrait Values Questionnaire" methodology (PVQ-21) (Sh. Schwartz, adapted in Russian by Davidov et al., 2008). This methodology is based on the value classification developed by Schwartz and assesses seven typological value indices (scales): "security" (safety and stability of society, relations and oneself), "conformance-tradition" (containing actions and motives that may harm others and do not meet social norms), "self-direction", "stimulation", "hedonism", "achievement-power" (social status, domination over people and resources), "care for people and nature" (benevolence, universalism). The subject evaluates 21 descriptions of people characterized by certain values on a 6-point scale - from " 1 not at all like me" to " 6 - very similar to me".

The resulting empirical data were processed using Friedman's two-factor dispersion analysis for related samples, factor analysis (using Varimax rotation with Kaiser Normalization), Mann-Whitney U-test. Calculations were made based on the SPSS 23 statistical software package.

\section{RESULTS}

To identify the value orientations (indices) using the PVQ-21 method, arithmetic mean (from 1 to 6) was calculated for each scale since the scales were measured in different ranges. The research made it possible to establish that for all scales of the PVQ-21 method, the average values correspond to the average level of formation of value indices (from 3 to 4 points). Friedman's two-factor dispersion analysis (Table 1) was used to identify dominant value orientations in the sample under study.

Table 1. Comparative analysis of the value orientation dominance among participants during the COVID-19 pandemic (PVQ-21).

\begin{tabular}{|c|c|c|c|}
\hline PVQ-21 Scales & $\mathbf{M}$ & Mean Rank & Friedman Test \\
\hline Benevolence-Universalism & 4.39 & 4.95 & \multirow{7}{*}{$\begin{array}{c}\chi^{2}=388,39 \\
\mathrm{p} \leq 0,001\end{array}$} \\
\hline Security & 4.13 & 4.34 & \\
\hline Self-Direction & 4.22 & 4.54 & \\
\hline Hedonism & 4.12 & 4.31 & \\
\hline Stimulation & 3.94 & 3.90 & \\
\hline Achievement-Power & 3.69 & 3.35 & \\
\hline Conformity-Tradition & 3.27 & 2.61 & \\
\hline
\end{tabular}

To test the second hypothesis of three prosocial behavioral strategies ("caring for others", "self-care through caring for others", and "self-care") during the COVID-19 pandemic, factor analysis was conducted. Results of the factor analysis determined three factors (Table 2). We applied R. Cattell's screen-test to determine the number of factors and made a scree plot for that purpose. The Point of inflection (K) of the eigenvalues determined the number of factors prior to the straight line after its sharp decline. The screen-test allows identifying the number of factors equal to $\mathrm{K}-1$. $\mathrm{K}, \mathrm{K}+1$. We used $\mathrm{K}+1$ quantity. The cumulative percentage (which indicates the informativeness of all factors) constitutes $72.52 \%$, which is an acceptable result. When interpreting the factors, we only considered those with factor loadings exceeding 0.6.

Table 2. Results of the factor analysis of the value orientation dominance among participants during the COVID-19 pandemic (PVQ-21).

\begin{tabular}{|c|c|c|c|}
\hline $\begin{array}{c}\text { Number } \\
\text { of } \\
\text { Factors }\end{array}$ & $\begin{array}{c}\text { Variance } \\
\text { Explained }\end{array}$ & $\begin{array}{c}\text { Variables Making up a } \\
\text { Factor } \\
\text { (Variable Weight) }\end{array}$ & Factor Name \\
\hline 1 & $42.37 \%$ & $\begin{array}{c}\text { Stimulation (0.829) } \\
\text { Self-Direction (0.759) } \\
\text { Benevolence-Universalism } \\
(0.619)\end{array}$ & $\begin{array}{c}\text { "caring for } \\
\text { others" } \\
\text { strategy }\end{array}$ \\
\hline 2 & $18.84 \%$ & $\begin{array}{c}\text { Conformity-Tradition (0.861) } \\
\text { Security (0.606) }\end{array}$ & $\begin{array}{c}\text { "self-care" } \\
\text { strategy }\end{array}$ \\
\hline 3 & $11.31 \%$ & $\begin{array}{c}\text { Achievement-Power (0.819) } \\
\text { Hedonism (0.608) }\end{array}$ & $\begin{array}{c}\text { "self-care } \\
\text { through } \\
\text { caring for } \\
\text { others" } \\
\text { strategy }\end{array}$ \\
\hline
\end{tabular}

To study the impact of the "volunteer experience" on the prosocial orientation during the COVID-19 pandemic (according to indicators of values orientation), we compared two groups using Mann-Whitney U-test (Table 3).

\section{DISCUSSION}

The data in Table 1 show that participants were dominated by the value of benevolence-universalism.

The factor analysis allowed distinguishing three types of social orientations of participants during the COVID-19 pandemic (Table 2).

The first type of social orientation can be characterized as "caring for others" proactive prosocial strategy. This type is defined by the values of benevolence (universalism, fairness), self-discretion, and stimulation (PVQ-21). Harvey and Erdos note that the psychological factors of risk-assisted behavior in an emergency area are altruism, heroism, and prosocial orientation of the individual [42]. Studies conducted in Spain showed that the health threat of COVID-19 predicted a tendency to express altruistic prosocial actions [43].

The second type of social orientation, defined by the values of security and conformism (PVQ-21), can be described as a conventional strategy. Conventional norms directly relate to the "self-care" prosocial strategy through respect for sanitary standards and norms of social distance. Ceylan \& Hayran note that compliance with restrictive measures is considered as prosocial behavior based on social responsibility [44]. V.R. Keiselman calls introjection a way to implement prosocial behavior. The introjection mechanism helps to suppress conflict with the dominant worldview and adapts a person to reality [45]. One of the factors of prosocial behavior and caring for others in a crisis is the emerging sense of common identity and collectivism, which stem from a common experience of being in straitened circumstances [46, 47]. Politi et al. found that prosocial attitudes during the COVID-2019 pandemic are driven by collective values and solidarity [48]. Developing a 
sense of loyalty can help coordinate threat management efforts and promote group commitment and social norms [49 - 51]. In doing so, the authorities (leaders) can have a significant impact on prosocial behavior by acting as role models $[52,53]$.

The third type of social orientation can be described as a selfish strategy, "self-caring through caring for others", defined by the values of hedonism and achievement-power (PVQ-21). A study conducted by Guo et al. found that prosocial coping with psychological pressures and stresses caused by the COVID-19 pandemic contributed to reducing mental health problems [37]. Banerjee \& Nair indicate that mutual help is an element of psychosocial intervention during the COVID-19 pandemic [54].

Yu Yamamoto, psychologist of the Tokyo Mental Health, among the measures to minimize the psychological consequences of the pandemic, points out the importance of altruism, empathy, and prosocial behavior not only about those who are important but also about those who are in a difficult situation (it can be one short phone call and one email). Yamamoto notes that as social animals, we humans strive for contact, compassion, and concern for nature and others [55].

O.I. Mahovskaya, replying to the question "How to behave in self-isolation due to the COVID-19 pandemic?" notes that those who help others survive in difficult periods generally live long [56].

R. Leahy developed a scheme, "What do I want to be during the COVID-19 pandemic?" which includes the position "I think about others and how I can help them" in the growth zone. Leahy offers the following recommendations during the COVID-19 pandemic: "Be supportive, ask for help and offer help! There is nothing more satisfying than to help a lonely person who is struggling or to help your loved ones, especially the elderly and the weak. Our feelings of belonging, gratitude, mutual support, and the substances that the body produces when we help others are the best immune assistants we have now" [57]. Thus, the strategy "I am for the World" becomes a resource for human development and psychological security [58].

Table 3. Comparison of participants in terms of value indices (PVQ-21), taking into account volunteer experience.

\begin{tabular}{|c|c|c|c|c|}
\hline \multirow[b]{2}{*}{ Indicators } & \multicolumn{2}{|c|}{ Mean Rank } & \multirow[b]{2}{*}{$\begin{array}{c}\text { Mann-Whitney } \\
\text { U-test }\end{array}$} & \multirow[b]{2}{*}{$p$} \\
\hline & $\begin{array}{c}\text { Experienced } \\
\text { in } \\
\text { Volunteering } \\
(\mathbf{n}=\mathbf{2 5 8})\end{array}$ & \begin{tabular}{|c|} 
Having no \\
experience \\
in \\
Volunteering \\
$(\mathrm{n}=189)$
\end{tabular} & & \\
\hline \multicolumn{5}{|c|}{ PVQ-21 scales } \\
\hline Benevolence-Universalism & 236.63 & 206.76 & 21123.5 & 0.015 \\
\hline Self-Direction & 238.75 & 203.87 & 20576 & $0.004^{*}$ \\
\hline Stimulation & 246.29 & 193.57 & 18630 & \begin{tabular}{|c|}
$<$ \\
$0.001^{*}$ \\
\end{tabular} \\
\hline Achievement-Power & 235.50 & 208.30 & 21414.5 & 0.028 \\
\hline Hedonism & 230.13 & 215.63 & 22799.5 & 0.238 \\
\hline Conformity-Tradition & 214.82 & 236.54 & 22011.5 & 0.078 \\
\hline Security & 222.27 & 226.37 & 23934 & 0.738 \\
\hline
\end{tabular}

Note: *statistically significant differences taking into account the Bonferroni correction (Significance Level $p \leq 0.007$ ).

The conducted research has shown that people experienced in volunteering have more developed values of self-direction and stimulation (Table 3). Thus, the volunteers' motives for providing assistance during the COVID-19 pandemic are primarily related to self-actualization [25].

\section{CONCLUSION}

One can expect prosocial behavior to manifest itself in different ways depending on individuals' group identity, psychological well-being, altruistic norms, and volunteers' experience to the extent that different emergencies affect the human psyche.

Despite any cross-cultural differences, the global data convincingly show that it is useful to activate values of selftranscendence and security in order to motivate people's behavior to support the mitigation of the pandemic. To reduce any negative social and psychological consequences of the COVID-19 pandemic, society and authorities should not rely on fear but collective control, compassion, support, and solidarity. Studies show that cultures that are accustomed to prefer security to freedom are easier to coordinate in the face of a pandemic.

The results of numerous studies in social psychology, clinical psychology, personality psychology, and neuropsychology have shown that "Self" maturity becomes the basis for compassion and caring for the Other. The self-care ability develops when one cares for others. The Other becomes a necessary participant in the process of self-consciousness and the formation of one's own identity. In emergencies, prosocial behavior can be a coping strategy.

Based on the obtained data analysis, it has been established that during the COVID-19 pandemic, the prosocial orientation may manifest itself in the following behavioral strategies: proactive prosocial strategy of "caring for others" (true altruism, expressed in forms of volunteering, helping a stranger, and charity despite the risk of contracting a coronavirus infection); egoistic strategy of prosocial behavior "self-care through caring for others" (volunteering based on self-development; helping a stranger to improve your own psychological well-being); conventional prosocial strategy "self-care" (self-isolation and preventive behavior).

In the long run, it is necessary to identify personal and environmental resources that allow people to effectively implement a prosocial self-isolation strategy during the COVID-19 pandemic, as well as various forms of volunteerism.

The resulting empirical results should be interpreted in light of several important limitations. First, it was a "convenience sampling". Thus, temporal order and causality cannot be verified. Future studies should use some longitudinal structures for further examination of the regularities we have found. The sampling is not necessarily representative of the entire society. Replication with the use of different sampling methods (gender, age, ethnicity, profession, etc.) is necessary. Future studies can confirm the reliability of the obtained results by analyzing various forms of prosocial behavior directly during the COVID-19 pandemic (volunteering, charity, membership in charity organizations, experience in helping a 
stranger, etc.) and personal characteristics (empathy, social identity, trust in the world, etc.).

\section{AUTHORS' CONTRIBUTIONS}

P.A.K. collected and evaluated the questionnaires, analyzedthe data, wrote the manuscript, designed the research, and statistical analyzed the data; E.A.S. advised on the theoretical aspects related to prosocial behavior.

\section{ETHICS APPROVAL AND CONSENT TO PARTI- CIPATE}

The study was conducted in accordance with the ethical code of The Russian psychological society, and the Protocol was approved by the Academic Council of the faculty of psychology of the Russian State Social University (Protocol No. 9 of 29.04.2020).

\section{HUMAN AND ANIMAL RIGHTS}

No animals were used in this research. All human research procedures were followed in accordance with the ethical standards of the committee responsible for human experimentation (institutional and national), and with the Helsinki Declaration of 1975, as revised in 2013.

\section{CONSENT FOR PUBLICATION}

The participants gave no informed consent to the publication as the data was collected anonymously through the Internet. The questionnaire included the item "I confirm that I have read and understood the purposes, procedure, method and possible inconveniences of participation in the research. I give my consent to participation in the research. I can give up or end the questionnaire at any time".

\section{AVAILABILITY OF DATA AND MATERIALS}

The data supporting the findings of the article is available from corresponding author [P.K] upon reasonable request.

\section{FUNDING}

The article was prepared within the framework of the grant of the President of the Russian Federation for state support of young Russian scientists (No. MD-83.2020.6).

\section{CONFLICT OF INTEREST}

The authors declare no conflict of interest, financial or otherwise.

\section{ACKNOWLEDGEMENTS}

Declared none.

\section{REFERENCES}

[1] Wolf LJ, Haddock G, Manstead ASR, Maio GR. The importance of (shared) human values for containing the COVID-19 pandemic. Br J Soc Psychol 2020; 59(3): 618-27. [http://dx.doi.org/10.1111/bjso.12401] [PMID: 32572981]

[2] Bavel JJV, Baicker K, Boggio PS, et al. Using social and behavioural science to support COVID-19 pandemic response. Nat Hum Behav 2020; 4(5): 460-71.

[http://dx.doi.org/10.1038/s41562-020-0884-z] [PMID: 32355299]

[3] Zaki J, Mitchell JP. Intuitive prosociality. Curr Dir Psychol Sci 2013;
22(6): 466-70.

[http://dx.doi.org/10.1177/0963721413492764]

[4] Penner LA, Dovidio JF, Piliavin JA, Schroeder DA. Prosocial behavior: multilevel perspectives. Annu Rev Psychol 2005; 56: 365-92.

[http://dx.doi.org/10.1146/annurev.psych.56.091103.070141] [PMID: 15709940]

[5] Twenge JM, Baumeister RF, DeWall CN, Ciarocco NJ, Bartels JM. Social exclusion decreases prosocial behavior. J Pers Soc Psychol 2007; 92(1): 56-66.

[http://dx.doi.org/10.1037/0022-3514.92.1.56] [PMID: 17201542]

[6] Barile L, Cullis J, Jones P. Will one size fit all? Incentives designed to nurture prosocial behavior. J Behav Exp Econ 2015; 57: 9-16. [http://dx.doi.org/10.1016/j.socec.2015.04.004]

[7] Kozlova MA, Kosheleva NV. Zabota o sebe i o drugom kak moralnaya ustanovka: mezhdisciplinarnyj podhod Care of the self and of the another as a moral attitude: An interdisciplinary approach Vestnik Pravoslavnogo Svyato-Tihonovskogo gumanitarnogo universiteta Seriya 4: Pedagogika Psihologiya 2015; 3: 94-105. [Bulletin of the Orthodox St. Tikhon's University for the Humanities. Series 4: Pedagogy. Psychology]

[http://dx.doi.org/10.15382/sturIV201538.94-105]

[8] Harbaugh WT, Mayr U, Burghart DR. Neural responses to taxation and voluntary giving reveal motives for charitable donations. Science 2007; 316(5831): 1622-5.

[http://dx.doi.org/10.1126/science.1140738] [PMID: 17569866]

[9] Bénabou R, Tirole J. Incentives and Prosocial Behavior IZA Discussion Papers 1695, Institute of Labor Economics. IZA 2005. [http://dx.doi.org/10.3386/w11535]

[10] Sagiv L, Roccas S, Cieciuch J, Schwartz SH. Personal values in human life. Nat Hum Behav 2017; 1(9): 630-9.

[http://dx.doi.org/10.1038/s41562-017-0185-3] [PMID: 31024134]

[11] Bardi A, Schwartz SH. Values and behavior: strength and structure of relations. Pers Soc Psychol Bull 2003; 29(10): 1207-20.

[http://dx.doi.org/10.1177/0146167203254602] [PMID: 15189583]

[12] Fischer R, Smith PB. Who cares about justice? The moderating effect of values on the link between organisational justice and work behaviour. Appl Psychol 2006; 55: 541-62.

[http://dx.doi.org/10.1111/j.1464-0597.2006.00243.x]

[13] Schwartz SH, Cieciuch J, Vecchione M, Torres C, Dirilen-Gumus O, Butenko T. Value tradeoffs propel and inhibit behavior: Validating the 19 refined values in four countries. Eur J Soc Psychol 2017; 47: 241-58.

[http://dx.doi.org/10.1002/ejsp.2228]

[14] Asmolov A, Bratus B, Dontsov A, Huseynov A, Ivannikov V, Magomed-Eminov M. Cultural-historical activity psychology in extreme situation: The pandemic challenge. Chelovek 2020; 31(4): $7-40$.

[http://dx.doi.org/10.31857/S023620070010929-8]

[15] Booth R. 2020.Community aid groups set up across UK amid coronavirus crisis. The Guardian. Retrieved from:: https://www.theguardian.com/society/2020/mar/16/community-aid-gro ups-set-up-across-uk-amid-coronavirus-crisis

[16] Holt GR. The pandemic effect: Raising the bar for ethics, empathy, and professional collegiality. Otolaryngology - Head and Neck Surgery $2020 ; 163(4): 621-2$.

[http://dx.doi.org/10.1177/0194599820933179]

[17] Yuan P. Caring for yourself and others during the COVID-19 pandemic: managing healthcare workers' stress. Compassion in Action Webinar Series 2020. Retrieved from: https://istss.org/ISTSS_Main/media/Documents/Schwartz-Center-Wat son-SFA-Final-PDF.pdf

[18] Europe U. European philanthropy and social investing impact hub 2020. EFC members' responses to COVID-19 pandemic. Retrieved from

https://www.efc.be/news-post/efc-publishes-efc-members-responses-to -covid-19-pandemic/

[19] Press-Release.ru. BRICS Business Magazine izuchit altruizm v epohu pandemii [BRICS Business Magazine will explore altruism in the age of the pandemic]. 2020. Retrieved from: http://www.press-release.ru/branches/org/brics_business_magazine_iz uchit_altruizm_v_epokhu pandemii_21_04_2020_10_19

[20] Levada-Centre. Grazhdanskoe obshchestvo v samoizolyacii [Civil society in self-isolation]. 2020. Retrieved from: https://www.levada.ru/2020/04/03/grazhdanskoe-obshhestvo-v-samoiz olyatsii/

[21] Institute of psychology RAS. \Otnoshenie rossiyan k epidemicheskim 
ugrozam (COVID-19) [Attitude of Russians to epidemic threats (COVID-19). 2020. Available from: https://ru.surveymonkey.com/r/pandemia

[22] WCIOM. Volontery pomogayut postradavshim ot pandemii [Volunteers help victims of the pandemic]. 2020. Retrieved from: https://wciom.ru/index.php?id=236\&uid=10233

[23] Slabinskii VYu, Voishcheva NM. K voprosu koncepcii proaktivnosti [Revisiting proactivity conception]. Medicinskaya psihologiya $\mathrm{V}$ Rossii 2016; 1 Available from: http://www.medpsy.ru/mprj/archiv_global/2016_1_36/nomer03.php

[24] WCIOM. From charity to volunteering: how charity is changing in Russia. 2019. Retrieved from: https://wciom.ru/index.php?id=236\&uid=9878

[25] Kislyakov PA, Shmeleva EA, Gowin O. Contemporary volunteering in the formation of prosocial behaviour of a person. Edu Sci J 2019; 21(6): 122-45.

[http://dx.doi.org/10.17853/1994-5639-2019-6-122-145]

[26] Raposa EB, Laws HB, Ansell EB. Prosocial behavior mitigates the negative effects of stress in everyday life. Clin Psychol Sci 2016; 4(4): 691-8.

[http://dx.doi.org/10.1177/2167702615611073] [PMID: 27500075]

[27] von Dawans B, Fischbacher U, Kirschbaum C, Fehr E, Heinrichs M. The social dimension of stress reactivity: Acute stress increases prosocial behavior in humans. Psychol Sci 2012; 23(6): 651-60. [http://dx.doi.org/10.1177/0956797611431576] [PMID: 22593119]

[28] Krysko VG. Socialnaya psihologiya. Moscow: Yurajt 2016. Social Psychology

[29] Luria G, Cnaan RA, Boehm A. National culture of indulgence as predictor of prosocial behavior: Governmental effectiveness as boundary condition. Voluntas 2019; 30: 1164-75. [http://dx.doi.org/10.1007/s11266-019-00124-5]

[30] Wilson N. Altruism in preventive health behavior: At-scale evidence from the HIV/AIDS pandemic. Econ Hum Biol 2018; 30: 119-29. [http://dx.doi.org/10.1016/j.ehb.2018.05.004] [PMID: 30016747]

[31] Roberto KA, Gigliotti CM, Husser EK. Older women's experiences with multiple health conditions: Daily challenges and care practices. Health Care Women Int 2005; 26(8): 672-92.

[http://dx.doi.org/10.1080/07399330500177147] [PMID: 16234211]

[32] Clarke LH, Bennett EV. Constructing the moral body: Self-care among older adults with multiple chronic conditions. Health 2013; 17(3): 211-28

[http://dx.doi.org/10.1177/1363459312451181] [PMID: 22773552]

[33] Kappes A, Nussberger AM, Faber NS, Kahane G, Savulescu J, Crockett MJ. Uncertainty about the impact of social decisions increases prosocial behaviour. Nat Hum Behav 2018; 2(8): 573-80. [http://dx.doi.org/10.1038/s41562-018-0372-x] [PMID: 31209312]

[34] Magomed-Eminov MSh. Psihologicheskie rekomendacii o povedenii i deyatel'nosti cheloveka v ekstremal'noj situacii pandemii (COVID-19) Psychological recommendations on human behavior and activity in an extreme pandemic situation (COVID-19). 2020. Retrieved from: http://www.psy.msu.ru/news/events/covid19/phyrecomend.pdf

[35] Pfattheicher S, Nockur L, Böhm R, Sassenrath C, Petersen M. 2020.The emotional path to action: Empathy promotes physical distancing during the COVID-19 pandemic. Preprint

[http://dx.doi.org/10.31234/osf.io/y2cg5]

[36] Kudryavceva E. The world after coronavirus: Is an epidemic of anxiety and depression waiting for us? Available from: https://trends.rbc.ru/trends/industry/5e9b19459a794782089aac96

[37] Guo J, Feng XL, Wang XH, van IJzendoorn MH. Coping with COVID-19: Exposure to COVID-19 and negative impact on livelihood predict elevated mental health problems in chinese adults. Int $\mathrm{J}$ Environ Res Public Health 2020; 17(11): 3857.https://www.mdpi.com/1660-4601/17/11/3857

[http://dx.doi.org/10.3390/ijerph17113857] [PMID: 32485859]

[38] Nestik TA. Coronavirus: Challenges to the individual, society and the state. 2020. Available from: https://psy.su/feed/8338/

[39] Dryhurst S, Schneider CR, Kerr J, et al. 2020.Risk perceptions of COVID-19 around the world. J Risk Res Available from: https://www.tandfonline.com/doi/full/10.1080/13669877.2020.175819 3

[http://dx.doi.org/10.1080/13669877.2020.1758193]

[40] WCIOM. 2020.Protect yourself from the coronavirus? Really! Available from: https://wciom.ru/index.php?id=236\&uid=10223
[41] Kislyakov PA, Shmeleva EA, Aleksandrovich MO. Moral grounds and social norms of safe prosocial behavior of youth. Education and Science Journal 2020; 22(6) [http://dx.doi.org/10.17853/1994-5639-2020-6]

[42] Harvey J, Erdos G. Psychological rewards and bad risks: The roles of prosocial antisocial moral and immoral attitudes values and beliefs as determinants of individual risk-taking behaviour: a framework for further research. In: Bedford T, Van Gelder PHA, Eds. Proceedings of the 14th European Safety and Reliability Conference (ESREL) 2003; 769-73.Newcastle. 2003; pp.

[43] Serrano-Montilla C, Alonso-Ferres M, Navarro-Carrillo G, Lozano LM, Valor-Segura I. Assessment of the effects of health and financial threat on prosocial and antisocial responses during the COVID-19 pandemic: The mediating role of empathic concern. Pers Individ Dif 2021; 178: 110855 .

[http://dx.doi.org/10.1016/j.paid.2021.110855]

[44] Ceylan M, Hayran C. Message framing effects on individuals' social distancing and helping behavior during the COVID-19 pandemic. Front Psychol 2021; 12: 579164.

[http://dx.doi.org/10.3389/fpsyg.2021.579164] [PMID: 33828501]

[45] Kejselman VR. Grani altruizma. Kiev: Feniks 2016. Verge of altruism

[46] Cruwys T, Stevens M, Greenaway KH. A social identity perspective on COVID $\square$ 19: Health risk is affected by shared group membership. Bri J Social Psychol 2020; 59(3): 584-93. Available from: https://www.scilit.net/article/c08eecc8a34797c283096b120c151ffe [http://dx.doi.org/10.1111/bjso.12391]

[47] McKinley GP. We need each other: Social supports during COVID 19. Social Anthropology 2020.May 1. Available from: https://onlinelibrary.wiley.com/doi/full/10.1111/1469-8676.12828 [http://dx.doi.org/10.1111/1469-8676.12828]

[48] Politi E, Van Assche J, Caprara GV, Phalet K. No man is an island: Psychological underpinnings of prosociality in the midst of the COVID-19 outbreak. Pers Individ Dif 2021; 171: 110534. [http://dx.doi.org/10.1016/j.paid.2020.110534]

[49] Drury J, Cocking C, Reicher S. The nature of collective resilience: Survivor reactions to the 2005 London bombings. Int J Mass Emerg Disasters 2009; 27(1): 66-95.

[50] Haslam SA, Reicher S. Stressing the group: Social identity and the unfolding dynamics of responses to stress. J Appl Psychol 2006; 91(5): 1037-52.

[http://dx.doi.org/10.1037/0021-9010.91.5.1037] [PMID: 16953766]

[51] Ellemers N, Spears R, Doosje B. Self and social identity. Annu Rev Psychol 2002; 53(1): 161-86.

[http://dx.doi.org/10.1146/annurev.psych.53.100901.135228] [PMID: 11752483]

[52] Schnall S, Roper JD. Elevation puts moral values into action. Soc Psychol Personal Sci 2012; 3: 373-8. [http://dx.doi.org/10.1177/1948550611423595]

[53] Yang XF, Pavarini G, Schnall S, Immordino-Yang MH. Looking up to virtue: averting gaze facilitates moral construals via posteromedial activations. Soc Cogn Affect Neurosci 2018; 13(11): 1131-9. [http://dx.doi.org/10.1093/scan/nsy081] [PMID: 30212913]

[54] Banerjee D, Nair VS. Handling the COVID-19 pandemic: Proposing a community based toolkit for psycho-social management and preparedness. Asian J Psychiatr 2020; 51: 102152.

[http://dx.doi.org/10.1016/j.ajp.2020.102152] [PMID: 32416531]

[55] Yamamoto $\mathrm{Yu}$. Impact of new measures to prevent coronavirus infection (COVID-19) on mental health. 2020. Available from: https://www.tokyomentalhealth.com/\%E6\%96\%B0\%E5\%9E\%8B $\%$ E3 $\% 82 \% \mathrm{~B} 3 \% \mathrm{E} 3 \% 83 \% \mathrm{AD} \% \mathrm{E} 3 \% 83 \% 8 \mathrm{~A} \% \mathrm{E} 3 \% 82 \% \mathrm{~A} 6 \% \mathrm{E} 3 \% 82 \% \mathrm{~A} 4 \%$ Е3\%83\%AB\%E3\%82\%B9covid-19\%E6\%84\%9F\%E6\%9F\%93\%E4 $\%$ BA $\% 88 \%$ E9\%98\%B2\%E5\%AF\%BE\%E7\%AD $\% 96 \%$ E3\%81\%AB $\% \mathrm{E} 3 \% 82 \% 88 \% \mathrm{E} 3 \% 82 \% 8 \mathrm{~B}-$

$\% \mathrm{E} 3 \% 83 \% \mathrm{~A} 1 \% \mathrm{E} 3 \% 83 \% \mathrm{~B} 3 \% \mathrm{E} 3 \% 82 \% \mathrm{BF} /$

[56] Mahovskaya OI. 2020.Hard at first, then easier. How to get used to self-isolation. Available at: https://www.svoboda.org/a/30548022.html

[57] Leahy R. 7 tips for handling isolation during the pandemic. 2020. Retrieved from: https://www.psychologytoday.com/us/blog/anxiety-files/202003/7-tips -handling-isolation-during-the-pandemic

[58] Fedosenko EV. Psychological problems of the meaning of life and acme. Proceedings of the 25th International symposium 2020; 34-47. 